International Journal of Business Management and Economic Review

Vol. 4, No. 05; 2021

ISSN: 2581-4664

\title{
INFORMAL SECTOR ENTREPRENEURSHIP, EMPLOYMENT AND INCLUSIVE GROWTH IN SOUTHEASTERN NIGERIA
}

\author{
Stella. I. Madueme \\ Department of Economics, University of Nigeria, Nsukka \\ Joan Chinonyelum Okafor \\ Department of Economics, University of Nigeria, Nsukka
}

http://doi.org/10.35409/IJBMER.2021.3313

\begin{abstract}
This study empirically examined the relationship between informal entrepreneurship, employment and inclusive growth in Southeastern Nigeria based on the neo-Schumpeterian framework. 500 respondents were randomly selected across the states in the southeastern region using a structured questionnaire. The Ordinary Least Square (OLS) technique was employed in analyzing the data. Informal sector entrepreneurship was measured by the number of business ownership, while employment was captured by informal wage and self-employment. An index of inclusive growth was constructed using income growth and equity in income distribution. Per capita household income growth was used as income growth and the differences in average income were used to capture equity in income distribution among the population of the study. The results of the study showed that informal sector entrepreneurship increases informal employment and directly impacted on inclusive growth but the indirect impact on inclusive growth through employment is insignificant. We recommended formalization of the informal sector, however, the formalization process should not be directed towards controlling and regulating. Instead, it should be enabling and supporting informal enterprises. The enabling methods should include the provision of suitable premises for entrepreneurs; organizing pieces of training on entrepreneurial skills development, employment practices and contracts, provision of water and electricity as well as low-interest loans and credits until they become more mature and ultimately part of the formal sector. This process will also fast formalize the informal sector, enhance growth and will bring about an increase in employment, earnings and more suitable job conditions for the poor.
\end{abstract}

Keyword: Informal Sector ,Entrepreneurship, employment and inclusive growth

\section{INTRODUCTION}

Over the years, there has been a growing awareness that entrepreneurs mostly in the developing countries are operating partly or wholly in the informal sector (Williams, 2015), especially in the first few years of operation. The informal sector is a major component of economic growth and development. It is a collection of businesses that are not registered and regulated, and in most cases, not taxed. They include enterprises that provide services and engage in production activities, market-trading and street vendor sales. The informal sector is well known for its employment generation and output growth. In developing countries such as Nigeria, informal employment is prevalent (Lucas, 2020). The sector reduces unemployment by creating a survival 


\section{International Journal of Business Management and Economic Review}

Vol. 4, No. 05; 2021

ISSN: 2581-4664

means to the large majority of the poor and the extremely poor individual and, therefore, improves the quality of life of the people and reduces crimes.

In Africa, the informal sector makes up the largest employer of labour. World Development Report (2019) showed that the informal sector constitutes over $70 \%$ of the total employment in sub-Saharan Africa and more than 60\% in South Asia and over 50\% in Latin America.The labour force growth is in the increase in Africa. African Economic Outlook - AEO (2019) projected the population of the working-age of Africans to increase from 705 million in 2018 to about 1 billion by 2030 . In Nigeria, the informal sector has been the dominant sector and largest employer. The sector's contribution to GDP of the national economy is about $60 \%$ and employees a larger proportion of the labour force in Nigeria. The increasing informal sector activities and the sector's contribution to GDP in the past decades have no doubts,placed Nigeriaamong the developing countrieswith the fastest and most sustained growth spurs. The estimated real GDP growth rate was $2.3 \%$ in 2019, which is marginally higher than the 2018 growth rate of $1.9 \%$ and $0.81 \%$ of 2017 (Nigeria Economic Outlook, 2020).However, this seems not to be proemployment.

Employment is expanding at a rate that is less than the annual growth in the labour force. The unemployed population has been on the increase every year. For example, in 2017, the unemployment rate was 17.46 per cent. But increased to 22.562 per cent in 2018. Between 2015 - 2016, the unemployment rate increased by 48.61\%, while between 2016 - 2017, the unemployment rate increased by $30.56 \%$. An increase of $29.21 \%$ unemployment rate was recorded between 2017 - 2018. In 2019, the unemployment rate stood at 23.1\%, putting half of the population below the poverty line of $\$ 381.75$ (IMF World Economic Outlook Data Base, 2019). The increasing rate of unemployment at the national level is an indication that growth in Nigeria has not beenpro-employment. A percentage increase in the growth rate of GDP over a period of 15 years was associated with just about $0.41 \%$ growth in employment (AEO, 2019). This means that employment is far less than the rate of labour force growth. Economic growth has not translated into job growth and inclusive, while the achievement of inclusive growth and employment creation has been the focus of economic policies of governments of developing countries.

Economic growth is said to be inclusive if it reduces poverty absolutely through productive employment creation instead of direct schemes of income redistribution. The main objective of inclusive growth is to facilitate productive employment and sustain it, achieving broad economic growth rates and improve the standard of living. The relationship between informal entrepreneurship, employment and inclusive growth is that the informal sector, which is the largest sector in most developing economies is the only option available for many vulnerable groups to enter into entrepreneurship and create employment for themselves and most others. Thus, informal entrepreneurship reduces unemployment. Reduction in unemployment is associated with better economic opportunities and more involvement or participation in economic activities by the working-age population with higher living standards. Even with the availability of unemployment benefits, informal sector employment can be said to have a higher income than unemployment.In other words, informal entrepreneurship and wage and selfemploymentreduce poverty,therefore, ensuring inclusiveness. Informal entrepreneurship is strategic for inclusive growth. 


\section{International Journal of Business Management and Economic Review}

Vol. 4, No. 05; 2021

ISSN: 2581-4664

In the southeastern region of Nigeria, informal entrepreneurship has become the most viable alternative to wage and self-employment.But not much impact on poverty and inequality is seen, meaning that economic growth and informal employment may not be inclusive. Perhaps,the reason for this could be that majority of the working-age population is not participating in the formal economy, but are either informally employed or unemployed. Income from informal employment is also very low. Low wages and poor living standards in the region is increasingly becoming an issue of concern. This could also be associated with the large subsistence informal economy in the region. Although, informal employment is better than unemployment and is expected to have a positive impact on inclusive growth. Informal entrepreneurship is capable of causing inclusive growth. The objective of this study is to examine the effect of informal sector entrepreneurship on inclusive growth and, also determine if this effect is dependent on informal wage and self-employment. This study has great policy relevance, for it will pave way for appropriate contemporary policies for inclusive growth is not just the Southeastern region, but also Nigeria as a whole.

\section{LITERATURE REVIEW Entrepreneurship}

Authors have defined entrepreneurship in different ways. Some authors see it primarily as innovation, while some other authors view entrepreneurship as a risk-taking. Some conceptualize it as a force that stabilizes the market and, another group of authors defined it as launching, owing, starting, and managing a business. Igbo (2005) defined entrepreneurship as the operation of one's business. To Kpelai (2013), entrepreneurship is a process of having and managing a new business venture or adding value to an already existing business. Bawa, Idris, Idris, and Leonard (2017) presented a similar definition in the study. According to them, entrepreneurship has to do with the process of discovering opportunities, and the exploiting of the opportunities.

An individual who is into entrepreneurship is called an entrepreneur. The concept of entrepreneur originated from the French word entreprendre, which means, "to undertake." An entrepreneur could, therefore, be described as an individual who sorts out, undertakes risk, controls, and manages an entrepreneurial business (Eriobunah \& Nosakhare, 2013). An entrepreneur is someone who either launches combinations of new factors of production like new techniques of producing given products, discovering the new market and sources of supply and organizational forms. An entrepreneur can also be described as an individual who owns and operates a business, takes risks, exploits market opportunities, and eliminates market supply and demand disequilibrium (Ezeibe, Diogu, Eze, Chiaha \& Nwokenna, 2013).

\section{Informal Sector}

Similar to entrepreneurship, the informal sector has been defined in different ways. Most authors view it from the perspective of government regulations. Some others view it from the point of social security, while the number of people employed in an enterprise was the yardstick used by some group of authors in categorizing the informal sector activities. Also, physical and human capital per worker, mode of entrepreneurial business operation, the source of income, and legal framework have been used as bases for defining informal sector (Ogbuabor \& Malaolu, 2013). Spring (2009) stated that the concept depicts unregistered, unregulated, and untaxed businesses, which include entrepreneurial production activities, services providing enterprises and street vendor sales. Dahlquist (2014) described the informal sector as a collection of commercial 


\section{International Journal of Business Management and Economic Review}

Vol. 4, No. 05; 2021

ISSN: 2581-4664

activities that are unregulated, which takes place outside the official or mainstream economy on a small scale, self-employed and casual, or non-regular basis. The informal sector is defined as the sector without binding official regulations but is under official regulations that do not force report of official returns on its or productive process (Onyebueke \& Geyer, 2011).

Informal sector enterprises are non-agricultural enterprises, usually small in terms of the number of employed persons, who are not incorporated and not registered (ILO, 2011). They are the enterprises that operate with no laid down regulations by the government or its agencies to control their organizational behaviour (Oduh, Eboh, Ichoku \& Ujah, 2008). These definitions suggest that informal sector enterprises are small, unregistered and without prescribed government regulations in areas such as restriction in entry into the sector, publication information regarding production processes, prices to sell a given product and prescribed safety and health standards.

\section{Entrepreneurship in the Informal Sector of Southeast Nigeria}

The informal sector is important and plays a relevant role in the development of the region. The sustaining power and 'ability' of the informal sector keep the Southeast economy going. The South East region's informal sector involves unregulated commercial/entrepreneurial activities, and the organizations are mainly small trading sector businesses and services, which firmly support the economy of the states in the region. The sector is providing income and, thereby, ameliorating the declining standard of living. The sector keeps increasing in size over the years with anincrease in entrepreneurs involved in entrepreneurial activities. Factors such as little job opportunity in the formal sector and poor management of the formal economy are identified as the reasons for the increasing informal sector entrepreneurship in the region. People in the region are increasingly becoming aware of the opportunities offered by the sector, seen the sector entrepreneurship as a second appropriate option to raise income, increase their self-worth and confidence and social and economic status in life. These factors have resulted in a large informal sector comprising of an increasing number of entrepreneurs.

\section{Informal Employment}

Informal employment comprises of both self-and wage-employment that are usually not protected by legal or regulatory frameworks. people employed in the informal sector are defined as all persons who, during a given reference period, were employed in at least one economic activity of the informal sector, irrespective of their status in employment and whether it was their main or a secondary job.

\section{Inclusive Growth}

Inclusiveness has been described by Anand, Mishra and Peiris (2013) as equity, equal opportunity for all, and market protection and transitions in employment.Inclusiveness and inclusive growth, in particular, has faced conceptual and measurement issues and diverse definitions have been prosed by authors. Hakimian (2013) stated that growth is inclusive when the benefits get to most of the people and not just the poor.In a narrower approach, Rauniyar and Kanbur (2010) described inclusive growth as a combination of growth and declining income 


\section{International Journal of Business Management and Economic Review}

Vol. 4, No. 05; 2021

ISSN: 2581-4664

disparities. Though narrow and easily measurable, this definition seems to exclude the nonincome group.

From another perspective, which is broader, Klasen (2010) characterised inclusive growth as growth everyone benefits from. In essence, for growth to be inclusive, it has to benefit everyone in the society; the very poor people, the close to poor, the middle-income group in the society, as well as the high-income group. The challenge with this definition is not about those to benefit from growth but the level and how the benefits are distributed also matters a lot and cannot be overlooked. For instance, if inclusive growth aims to improve income and reduce inequality between the poor and the rich, then the benefits of inclusive growth need not be proportionate. In other words, the distribution of growth has to be progressive to mostly benefit the poor.

A defining challenge in the above definitions is that they all view inclusive growth from the perspective of income elements with most emphasis on outcomes. However, most recent studies have characterized inclusive growth as a growth process and not an outcome alone, and involves non-income elements. They point out the role of opportunities in the achievement of inclusive growth. For instance,Ianchovichina and Gable (2011) defined inclusive growth like that, which provides equal playing ground for investment and generating productive employment opportunities. It is a growth that reduces poverty and provides equal opportunities for every part of the population. It is a growth that creates opportunities for the people and making the opportunities assessable for everyone, especially the poor. Going by these definitions, inclusive growth is a process that provides better opportunities for individuals to benefit from growth.

The relationship between informal sector entrepreneurship,employment and inclusive growth is on the basis that informal entrepreneurs contribute diverse ideas and a lot of energy and capital resources to their various communities and regions, generate jobs opportunities and other spin-off business linkages for the people, relevant for the inclusive growth.Informal sector entrepreneurship creates a process that provides jobs (though, in most cases with low income) for individuals that better their lives, therefore, making them benefit from informal sector growth in particular, and economic growth generally. This is a motivation for individuals to be hardworking and look forward to better opportunities mostly by their efforts. Inclusive growth can be achieved if better opportunities are created (including job opportunities - wage and self-employment) and making sure that these opportunities are equally made accessible to every segment of people in society.

\section{Empirical Study}

The empirical font includes the study by Akpodono (2016) who examined the relationship between entrepreneurship and employment generation in Southeastern Nigeria. A sample size of 553 entrepreneurs was primarily collected using questionnaires and direct interviews. The author employed the Pearson, Kendall and Spearman correlation and simple regression techniques. The findings of the study showed that the contributions of entrepreneurs significantly and positively affected employment generation. Adebosin (2019) examined the relationship between employment, poverty and inclusive growth in Nigeria from $1980-2015$ using the dynamic ordinary least square cointegration technique. Inclusive growth was proxied by Gross domestic product per capita. The study found a positive and insignificant impact of 


\section{International Journal of Business Management and Economic Review}

Vol. 4, No. 05; 2021

ISSN: 2581-4664

poverty and employment on inclusive growth. Focusing on European Union countries, Georgescu and Herman (2019) examined the interrelationship between productive employment, and inclusive and sustainable development from 2007 - 2016. The study found high labour productivity, the efficient sectoral structure of employment, low employment and working poverty has the main determinant of inclusive growth. In South Africa, Meyer (2017) examined the relationship between employment and economic growth from 2002 - 2016. The Grangercausality technique was employed by the author. The study found unidirectional causality from economic growth and repo rate to employment.Tarilaye and Okoye (2017) examined the relationship between entrepreneurship financing and inclusive growth in Nigeria, focusing mainly on the challenges and prospects of inclusive growth. The study foundcorruption and its impact on the economy as the key challenge of inclusive growth. Employing a multivariate Panel Logit model, Yelwa, Obansa and Owe (2015) examined the impact of informal sector activities, inclusiveness and economic growth in Nigeria. The study makes use of 150 respondents from the informal sector. A positive and significant impact of informal sector activities on economic growth was found.

Though both national and across country studies on inclusive growth are found. However, none of the studies, especially in the developing countries including Nigeria as directly examined the relationship between informal sector entrepreneurship, employment and inclusive growth. Adebosin (2019) who examined the relationship between employment, poverty and inclusive growth in Nigeria did not capture informal entrepreneurship. Thus, our study differs from his study. Also, the study of Adebosin (2019) is a macro study, while our study is a micro-study. Also, Adebosin (2019) measured inclusive growth with the Gross domestic product per capita, which does not capture inclusiveness in its broad sense. Therefore, the findings of his study are not robust. Similarly, Akpodono (2016) who examined the relationship between entrepreneurship and employment generation in the South Eastern region of Nigeria did not include inclusiveness in her study. Therefore, by examining the direct and indirect impact of informal entrepreneurship and employment on inclusive growth, this study differs from her study.

\section{METHODOLOGY}

\section{The population of the Study}

The population of this study is informal sector entrepreneurs in the Southeastern region of Nigeria. It includes entrepreneurs in all the sub-sectors of the informal sector such as the trade and services sub-sectors in all the states in the region.The region is one of Nigeria's six geopolitical zones, geographically located in Southeastern Nigeria. The region consists of five states, which are Abia State, Anambra State, Ebonyi State, Enugu State, and Imo State. The Southeastern Region of Nigeria is bounded on the west by the River Niger, to the East by Akwa Ibom state, to the South by rivers state and to the North by Benue state.

\section{Sample and Sampling Technique}

A sample of 500 informal sector entrepreneurs was selected for this study. Two Local Government Areas (LGAs) were selected randomly from each of the states. Thereafter, four communities were selected from each of the LGA apart from the purposive selection of the LGA headquarters, given 50 communities. Also, 10 informal sector entrepreneurs were selected from each of the communities. Therefore, making the total number of respondents for this study to be 500. Structured Questionnaires were used to collect data for the study. The designed instruments 


\section{International Journal of Business Management and Economic Review}

Vol. 4, No. 05; 2021

ISSN: 2581-4664

comprise multiple-choice close-ended questions as well as open-ended questions.

Measurement of Inclusive Growth

Informal sector entrepreneurship contributes to economic growth by generating job opportunities and improving productivity, which is directly related to achieving inclusive growth outcomes. Ali and Son (2007)pointed out three basic measures that play a key role in achieving inclusive growth outcomes. These are generating employment opportunities and enhancing productivity; human capital development through investment in education and health; and provision of social safety nets and interventions to the vulnerable population. Our concern in this study is employment generation and productivity enhancement.

For this study, an index of inclusive growth is constructed. Following Anand, Mishra and Peiris (2013), inclusive growth depends on income growth and income distribution. Two properties that must be satisfied by the social welfare function to be employed is that; (i) to capture the growth dimension, it has to be increasing in its arguments and (ii) to capture the distributional dimension, it has to satisfy the transferred property - income transfer from a poor individual to a richer individual reduces the value of the function.

The concentration curve is the basis for the measurement of inclusiveness. Following Ali and Son (2007) and Anand, Mishra and Peiris (2013), a concentration curve, called social mobility curve is specified as follows:

$G C^{c} \approx\left(y_{1}, \frac{y_{1}+y_{2}}{2}, \ldots \frac{y_{1}+y_{2}+\ldots+y_{n}}{n}\right)$

Where $\mathrm{n}$ in equation (1) represents the number of people in the population, while $y_{1}, y_{1},$. . $y_{i}$ represent incomes from the poorest to the richest individual. It is assumed that the two properties stated above are satisfied. Following Anand, Mishra and Peiris (2013), the degree of the change income distribution can be estimated from the area under the social mobility curve as shown below:

$\bar{y}^{*}=\int_{0}^{100} \bar{y}_{i} d_{i}$

For equitable distribution of income, $\bar{y}^{*}$ will be an equal to $\bar{y}$. Distribution of income is inequitable if $\bar{y}^{*}$ is less than $\bar{y}$. In other words, the inequitable distribution of income is simply the deviation of $\bar{y}^{*}$ from $\bar{y}$. This characteristic of $\bar{y}^{*}$ was what Ali and Son (2007) employed in constructing an index of equity, defined as:

$v=\frac{\bar{y}^{*}}{\bar{y}}$.

The value of $\mathrm{v}$ is 1 if income is wholly equitably distributed. The closer the value of $\mathrm{v}$ to 1 , the more equitable income distribution becomes. We make $\bar{y}^{*}$ in equation (3) to be the subject of the formula as:

$\bar{y}^{*}=v * \bar{y}$

Growth is inclusive if $\bar{y}^{*}$ increases, which requires increasing average income resulting from growth (that is, increasing $\bar{y}$ ), increasing the index of equity income resulting from increasing equity (that is, increasing v) or by increasing average income and the index of equity income jointly. Equation (4) can be differentiated to capture the contributions of increase in average income to inclusive growth, keeping income distribution constant, as well as the contribution of change in income distribution without any change in average income. This is presented in equation (5) as:

$d \bar{y}^{*}=v * d \bar{y}+d v * \bar{y} \quad$. . . . 
International Journal of Business Management and Economic Review

Vol. 4, No. 05; 2021

ISSN: 2581-4664

Where $d \bar{y}^{*}$ measures the change in inclusive growth, $v * d \bar{y}$ measures contributions of increase in average income to inclusive growth, while $d v * \bar{y}$ captures the contribution of change in income distribution without any change in average income (Anand, Mishra and Peiris, 2013). Based on the above, we measure an index of inclusive growth by taking per capita household income growth as income growth and differences in average income to capture equity in income distribution among the population of the study.

Theoretical Framework

This study is built on the neo-Schumpeterian theory, which links economic growth/development and innovation. This theory relates to higher growth and development to entrepreneurial skills in the economy. It is an extension of the endogenous growth model to explain how knowledge is converted into economically useful firm-specific knowledge and its influence on development. The theory built on the later Schumpeter's (1942) ideas or concept of creative destruction as the core process through which the upward movement of innovative technological progress takes place (Aghion \& Howitt, 2009).

Following Acs, Audretsch, Braunerhjelm \& Carlsson (2004) and assuming that the allocation choice of individuals between savings and consumption is determined by their discounted utility over a lifetime, and savings are invested in research and development (R\&D) - investment, which is related to the instantaneous market rate of interest (r), the Schumpeterian basic utility function can be presented as:

$U=\int_{0}^{\infty} e^{-p t} \operatorname{In}[h()] d$.

where the sub-utility function $h($.$) explains how the utility is increasing new knowledge (\alpha)$ of existing goods (y),

$h\left(y_{0}, y_{1}, y_{2}, \ldots.\right)=\sum_{n=0}^{\infty} \alpha y_{n} \alpha>1$.

If the prices of the previous quality are assumed to be one, the consumer is ready to pay $\alpha(>1)$ for the new quality-enhanced product (the outcome of R\&D races between firms). As consumers move their attention to the new product, resources are switched from the production of old products to new products that mean, creative destruction occurs (Aghion \& Howitt, 1992).

Every new race improves on former investment in knowledge. As firms hire labour to carry out research and increase their firm-specific knowledge, $\left(l_{i, R}\right)$, they improve their likelihood of winning the $R \& D$ race (commercializing knowledge). A winner of the $R \& D$ race will benefit a short period of monopoly market power, which stimulates additional investment in R\&D and new races. This form of quality-improving innovations comes into the market through the Poisson process by probability $(\mu)$,

$\mu=\left(\sum_{i}^{n} l_{i, t}\right) d t=l_{R}^{\gamma} d t$

where the technology assumed in knowledge production implies decreasing returns to scale $(0<$ $\gamma<1)$.

The growth of the economy is influenced by the preferences of the consumers for the enhanced quality product, that is, $h\left(y_{0}, y_{1}, y_{2}\right.$, . . . . . In steady-state growth, consumption and knowledge investment never changes over time, but new qualities increase consumer utility. This points out that growth is determined by the innovative ability to commercialize knowledge investment, $t l_{R}^{\gamma} \ln \alpha$. Therefore, 
International Journal of Business Management and Economic Review

Vol. 4, No. 05; 2021

ISSN: 2581-4664

$g=d G \frac{(t, Y)}{d t}=l_{R}^{\gamma} \ln \alpha$

(9)

This means that growth increases in knowledge investment, (hiring additional R\&D workers, and $\left.\mathrm{L}_{\mathrm{R}}\right)$. In other words, the level in which innovations go into the market $(\mu)$, the degree of quality improvement $(\alpha)$ derives growth but decreases in the degree of diminishing returns to scale $(\gamma)$.

Though this model has good features, it does not capture the characteristics of the core Schumpeterian entrepreneur, it combines entrepreneurial skill and the stock of knowledge to innovate, thus, reducing the filter between general knowledge and economically useful or productive knowledge. Therefore, to incorporate the innovative entrepreneur into the neoSchumpeterian framework, we bring in some modifications in line with Acs, Audretsch, Braunerhjelm and Carlsson (2004). Assume that start-ups of new entrepreneurial firms take place in the same way as new qualities are introduced into the market. That is, a subset of a population, $\bar{L}$ individuals will come as entrepreneurial start-ups, governed by a Poisson process,

$\eta d t=\left(\sum_{i=1}^{L_{0}} l_{i, E}(\bar{e}, A, \sigma)\right) d t=\sigma_{E} L_{E}^{\gamma} d t \quad$. . . . (10)

where $\bar{e}$ is an entrepreneurial capability, A is available knowledge and $\sigma_{E}$ is the entrepreneurial efficiency or filter parameter that enders or enhances commercialization of knowledge through entrepreneurial activities. $(0<\gamma<1)$ implies decreasing returns to scale in aggregate production. The instinct for decreasing returns to scale in entrepreneurial activities is that incumbent and large entrepreneurial firms had better perform some tasks.

With the assumption of independence between entre into the market through R\&D-races and entry through pure entrepreneurship, we can use the additive property of Poisson distribution, following Acs, Audretsch, Braunerhjelm and Carlsson (2004) as,

$k d t=\mu d t+\eta d t=\left(\sigma_{R} L_{R}^{\gamma}+\sigma_{E} L_{E}^{\gamma}\right) d t$

Expressing equation (11) in terms of long-run steady-state growth would yield,

$g^{*}=d G / d t=\left(\sigma_{R} L_{R}^{\gamma}+\sigma_{E} L_{E}^{\gamma}\right) \ln \alpha$

which exceeds the expression presented in equation (4.4), given that $L_{E}>0$. Therefore,

$g=\sigma_{R} L_{R}^{\gamma} \ln \alpha<\left(\sigma_{R} L_{R}^{\gamma}+\sigma_{E} L_{E}^{\gamma}\right) \ln \alpha=g^{*}$.

Hence, a higher rate of intensity in the commercialization of knowledge generates higher growth (Acs, Audretsch, Braunerhjelm \& Carlsson, 2004). The R\&D - variables refers to research-based entry $\left(L_{R}\right)$ by incumbents, while the entrepreneurship variable is associated with core entrepreneurs $\left(L_{R}\right)$.Inclusive growth is positively associated with growth and, we substitute growth in equation (13) with inclusive growth. Thus, we re-write equation (13) as:

ngrowth $=\sigma_{R} L_{R}^{\gamma} \ln \alpha<\left(\sigma_{R} L_{R}^{\gamma}+\sigma_{E} L_{E}^{\gamma}\right) \ln \alpha=$ ngrowth $^{*} . \quad$. .

Where ngrowth is inclusive growth.

\section{Model Specification}

This paper specifically examines the effect of informal sector entrepreneurship on inclusive growth and, also, determines if this effect is dependent on the level of employment.In equation (14), it is specified that ngrowth $=\left(\sigma_{R} L_{R}^{\gamma}+\sigma_{E} L_{E}^{\gamma}\right) \ln \alpha$. Wherengrowth is inclusive growth, $\left(L_{R}\right)$ refers to research-based entry $\mathrm{R} \& \mathrm{D}$-variables by incumbents, while $\left(L_{E}\right)$ is the entrepreneurship variable associated with core entrepreneurs. $\sigma_{R}$ and $\sigma_{E}$ represent the efficiency - or filter - parameters that could either hampers or facilitates entrepreneurial growth. Substitute $L_{E}$ with entrepreneurship (ENT) - measured by the number of business ownership; and $L_{R}$ with years of entrepreneurial experience (ENEX). To capture the relevance of knowledge (R\&D) 


\section{International Journal of Business Management and Economic Review}

Vol. 4, No. 05; 2021

ISSN: 2581-4664

spillovers for informalentrepreneurs, we interact with the R\&D-variable (ENEX) with entrepreneurship (ENT) following Acs, Audretsch, Braunerhjelm and Carlsson (2004). The reason for the interaction is to examine the contribution of knowledge spillover to inclusive growth. Two control variables, financial or other forms of assistance (ASS) from the government, organizations or individuals are included to represents the efficiency - or filter - a parameter that captures support for entrepreneurship development; while business capital is included to capture the impact of business capitalization on inclusive growth. The functional form of the model is, therefore, presented as:

NGROWTH $=f\left(E N T, E N E X, E M P L, E N T \_E N E X, A S S, C A P I T A L\right)$. . (15)

Besides, to determine the role of employment in inclusive growth, again, we interact employment with entrepreneurship. We, therefore, rewrite equation (15) as:

NGROWTH $=f\left(E N T, E N E X, E M P L, E N T \_E N E X, E N T \_E M P L A S S, C A P I T A L\right) \ldots$ (16)

After taking the log of the variables, we specify the model for estimation as:

NGROWTH $=a_{0}+a_{1}$ ent $+a_{2}$ enex $+a_{3}$ enex $+a_{4}$ ent_enex $+a_{5}$ ent_empl $+a_{6}$ ass + $a_{7}$ capital $+u_{1} \ldots(17)$

Where all the variables remained as defined above with the lowercased variables representing log-transformed, and $\mathrm{u}_{1}$ is the error term. NGROWTH is not logged since the index is already in rates. The $\alpha$ 's respectively are the parameters to be estimated. ASS is a dummy variable, which takes the value of 0 if the entrepreneur does not get any form of support and 1 if the entrepreneur gets any form of support. All the explanatory variables are expected to have a positive impact on the explained variable.

The Ordinary Least Square (OLS) regression technique is employed to estimate the model. OLS estimator is Best Linear Unbiased Estimator (BLUE) in the class of all available estimators if the assumptions such as linearity, zero value of the expected disturbance term among others hold. A multicollinearity test would be carried out to ascertain the linear relationship between the explanatory variables. This test is necessary to avoid the consequences of the presence of multicollinearity in a regression such as in incorrect variances, and, therefore, estimation precision.

\section{RESULTS}

\section{Demographic Characteristics of the Respondents}

The demographic characteristics of the respondents considered in this study are age, marital status, education and household. The distribution of the demographic characteristics of the respondents is reported in Table 5.1 below:

Table 1: Descriptive Statistics of the Respondents' Profiles

\begin{tabular}{lll}
\hline & Frequency & $\%$ \\
\hline Gender & & \\
Males & 260 & 52.00 \\
Females & 240 & 48.00 \\
Total & $\mathbf{5 0 0}$ & $\mathbf{1 0 0 . 0 0}$ \\
\hline Age group & & \\
Below 30 years & 138 & 27.60 \\
$30-44$ years & 174 & 34.80
\end{tabular}


International Journal of Business Management and Economic Review

Vol. 4, No. 05; 2021

ISSN: 2581-4664

\begin{tabular}{lll}
\hline \hline $45-59$ years & 126 & 25.20 \\
60 and above & 62 & 12.40 \\
Total & $\mathbf{5 0 0}$ & $\mathbf{1 0 0 . 0 0}$ \\
\hline Marital status & 131 & \\
Single & 210 & 26.20 \\
Married & 84 & 42.00 \\
Divorced & 75 & 16.80 \\
Widower & $\mathbf{5 0 0}$ & 15.00 \\
Total & & $\mathbf{1 0 0 . 0 0}$ \\
\hline Education Level & 38 & \\
No Education & 91 & 7.60 \\
Primary & 143 & 18.20 \\
Secondary & 151 & 28.60 \\
Tertiary & 77 & 30.20 \\
Others & $\mathbf{5 0 0}$ & 15.40 \\
Total & & $\mathbf{1 0 0 . 0 0}$ \\
\hline Household size & 195 & \\
Below 5 person & 209 & 39.00 \\
5-9 persons & 86 & 41.80 \\
10-14 persons & 10 & 17.20 \\
15 and above & $\mathbf{5 0 0}$ & 2.00 \\
Total & $\mathbf{1 0 0 . 0 0}$ \\
\hline
\end{tabular}

Source: Authors computation from field survey, 2018

The Table shows that the females are 240 , representing 48 per cent of the total respondents while the males are 260 , representing 52 per cent of the total respondents. The analysis, therefore, shows that the respondents were more of males.

As regards the respondents' age range, 138 or 27.60 per cent of the respondents were below 30 years, 174 or 34.80 per cent were between the age ranges $30-44$ years, 126 or 25.20 per cent were between the age ranges 45 - 59 years, while 62 or 12.40 per cent were 60 years and above. Therefore, the majority of the respondents were between the age ranges of $30-44$ years.

As indicated in Table 1, 131 or 26.20 per cent of the respondents were single, 210 or 42.00 per cent were married, 84 or 16.80 per cent of the respondents were divorced, and 75 or 15.00 per cent of the respondents were widowers. Therefore, the respondents were more of married people. The household size of the respondents as presented in Table 1 showed that 195 or 39.00 per cent had a household size of below 5 persons, 209 or 41.80 per cent had a household size of $5-9$ persons, 86 or 17.20 per cent had a household size of $10-14$ persons, while 10 or 2.00 per cent had a household size of 15 persons and above. Therefore, the majority of the respondents' households were between 5 - 9 persons.

38 or 7.60 per cent of the respondents had no formal education, 91 or 18.20 per cent had primary education, and 143 or 28.60 per cent had secondary education. Those with tertiary education were 151 or 30.20 per cent, and 77 or 15.40 per cent had other forms of education. Therefore, the majority of the respondents in the region had tertiary education.

Informal Entrepreneurship Characteristics in the Southeastern Region

The informal entrepreneurship characteristics in the Southeastern region were examined and 


\section{International Journal of Business Management and Economic Review}

Vol. 4, No. 05; 2021

ISSN: 2581-4664

shown in Figure 1 below.

Figure 5.1: Informal entrepreneurship characteristics in Southeastern Nigeria

a. Business ownership structure

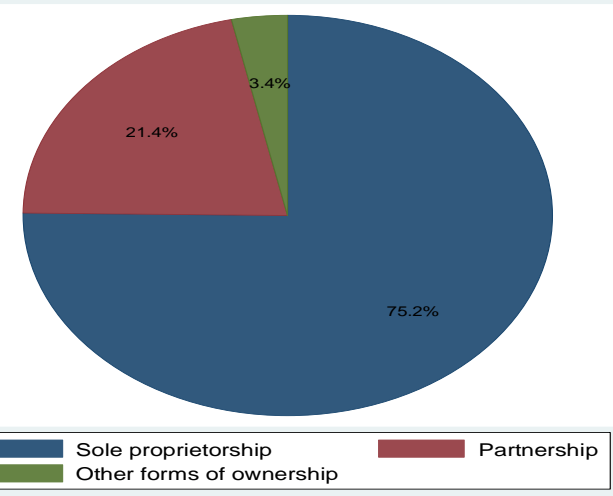

b. Business capital range

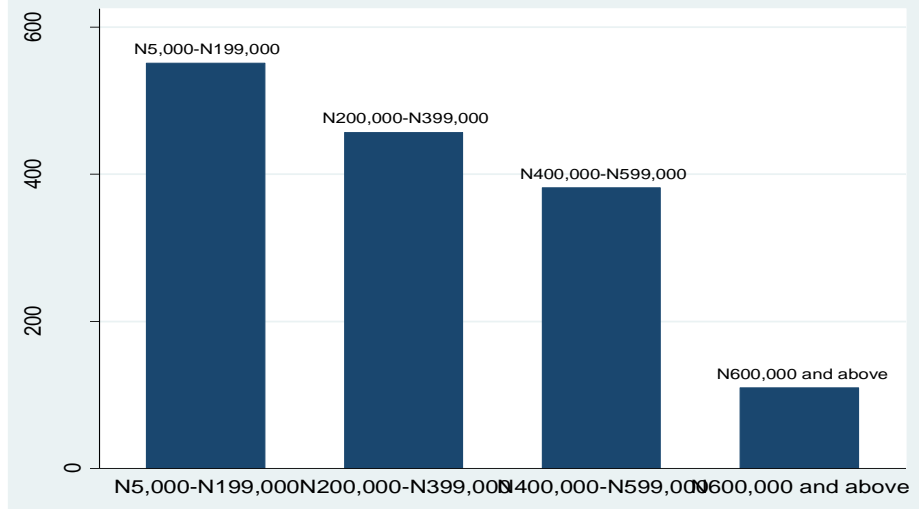

b. Type of business

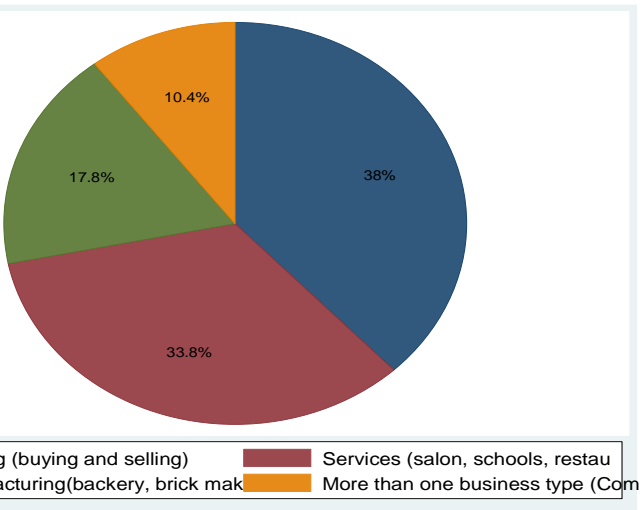

c. Sources of finance

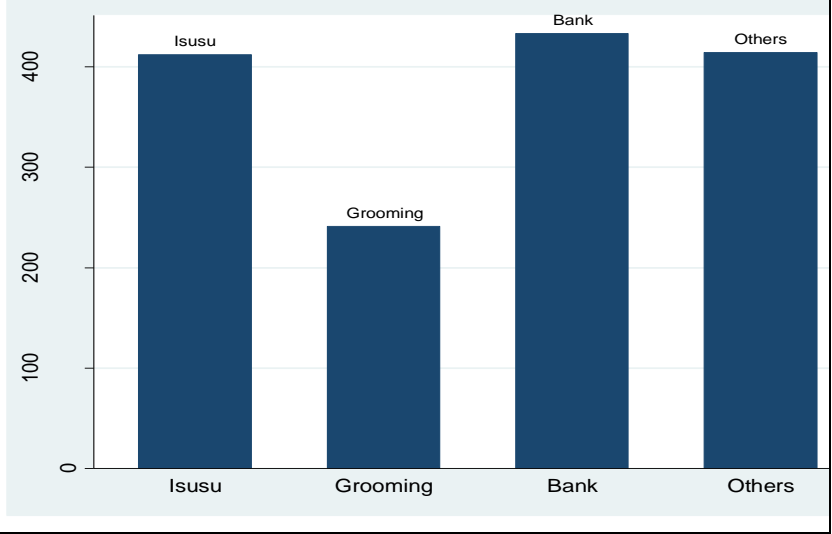

e. Business activity records

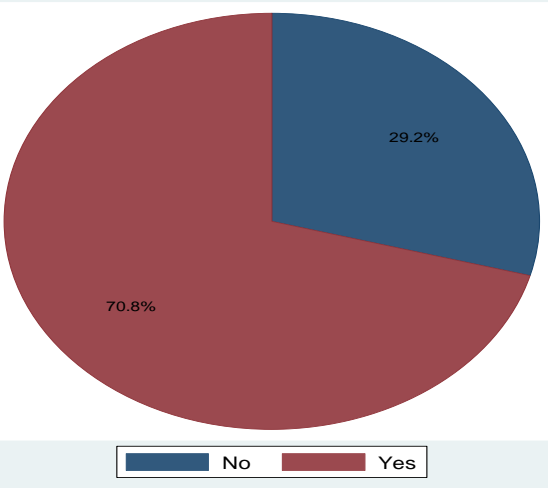

f. Receives business contract

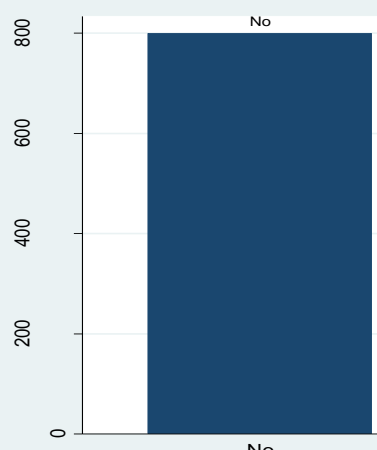

No

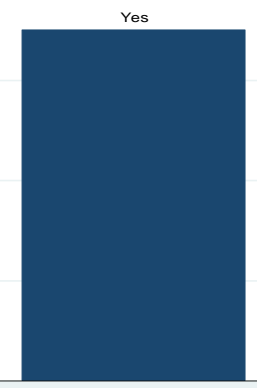

Yes

Source: Author's plot from field survey

Concerning the ownership structure of the businesses, entrepreneurs in Southeastern Nigeria are more of a sole proprietorship, characterized by a single owner who manages, take the business risk, and bear the loss or take profit alone. As shown in panel (a) of Figure 1, 75.2 per cent of 


\section{International Journal of Business Management and Economic Review}

Vol. 4, No. 05; 2021

ISSN: 2581-4664

businesses in the region is a sole proprietorship, 21.4 per cent is partnership businesses, while 3.4 per cent is another form of ownership such as limited liability companies.

Panel (b) in Figure 1 showed the statistics of types of businesses commonly engaged by entrepreneurs in the region. 38.00 per cent of entrepreneurs are into trading only, 17.8 per cent is only manufacturing, and 33.8 per cent is into services provision only, while 10.4 per cent has a combination of businesses. Therefore, the most common type of business among informal sector entrepreneurs in the region are trading such as buying and selling, and provision of services such as schools, salon, restaurants and computer services.

The business capital of the entrepreneurs was grouped into 4. The first group has a capital range of between $\$ 5,000$ - $\$ 199,000$ and the second group has a business capital range of $\$ 200,000-$ $\$ 399,000$. Those with a capital range of $\$ 400,000$ - $\$ 599,000$ were grouped, while entrepreneurs with a capital of $¥ 600,000$ and above were also grouped. As shown in panel (c) of Figure 1, entrepreneurs with a capital range of $\$ 5,000-\$ 199,000$ were more than entrepreneurs whose capital range was either $\$ 200,000$ - $\$ 399,000$; $\$ 400,000$ - $\$ 599,000$ or $\$ 600,000$ and above. This means that most of the entrepreneurs in the region have small capital ranging between $\$ 5,000$ - $\$ 199,000$.

Four sources of business capital were considered in this study. These are Isusu, bank, grooming and other sources of capital. It showed (see panel d) that entrepreneurs source for capital majorly from the bank, followed by Isusu and other sources. Grooming was the list source of entrepreneurial capital.

Concerning business activity records keeping, the result showed that 70.8 per cent of entrepreneurs keep business records, while 29.2 per cent of the entrepreneurs do not keep business records. Therefore, a large number of entrepreneurs in the region have business records. On the other hand, as shown in panel (f) of Figure 1, entrepreneurs in the region are mostly without a contract. Those that get business contract were less than those that do not get a business contract. This perhaps is determined by the ownership structure, size of the business and the type of business. As discussed earlier, the ownership structure is a majorly sole proprietorship, which is usually the small size and the leading business type is trading - buying and selling.

Impact of Informal Sector Entrepreneurship and Employment on Inclusive Growth Equation (17) was estimated to examine the impact of informal sector entrepreneurship and employment on inclusive growth using the OLS technique and the result is presented in Table 2 below.

Table 2: Results of the impact of informal sector entrepreneurship and employment on inclusive growth

\begin{tabular}{lllll}
\hline NGROWTH & Coefficients & $\begin{array}{l}\text { Standard } \\
\text { Errors }\end{array}$ & t-stat & P-value \\
\hline ent & 2.5888 & 1.1455 & 2.26 & 0.023 \\
enex & 5.0392 & 2.1721 & 2.32 & 0.017 \\
empl & 9.2471 & 19.6747 & 0.47 & 0.637 \\
ent_enex & 1.5168 & 0.6926 & 2.19 & 0.044 \\
ent_empl & 2.6851 & 89.5046 & 0.03 & 0.973 \\
\hline
\end{tabular}


International Journal of Business Management and Economic Review

Vol. 4, No. 05; 2021

ISSN: 2581-4664

\begin{tabular}{lllll}
\hline \hline capital & 19.1308 & 8.5067 & 2.25 & 0.025 \\
ass & -1.0500 & 7229431 & -1.45 & 0.147 \\
Constant & 3.6500 & 1.9300 & 1.89 & 0.060 \\
\hline R-squared & 0.7196 & & \\
Adj R-squared & 0.7038 & & \\
F-statistics & $9.24(\mathrm{p}=0.0273)$ & & \\
Ramsey RESET statistics & $0.53(\mathrm{p}=0.6648)$ & & \\
\hline
\end{tabular}

Source: Computed by the authors

The coefficient for entrepreneurship is positive. This means that entrepreneurship has a positive impact on inclusive growth. Specifically, an increase in informal sector entrepreneurship leads to $2.59 \%$ increase in inclusive growth in southeastern Nigeria. The significant $t$-value points to the rejection of the null hypothesis that informal sector entrepreneurship has no statistically significant impact on inclusive growth in the study area. Informal sector entrepreneurship significantly results in inclusive growth. The result also shows a positive and significant coefficient for years of entrepreneurial experience. This means that the number of years an entrepreneur stays in business plays a significant role in determining inclusive growth. The longer an entrepreneur in the informal sector is in the business, the more inclusive growth becomes. This is because, the duration ofentrepreneurial experience grows personal and corporate innovativeness and builds confidence in entrepreneurial innovation necessary for entrepreneurial growth and, consequently, inclusive growth. Looking at the employment variable, the result shows a positive and insignificant coefficient, indicating that employment is a positive and insignificant determinant of inclusive growth.Employment is a survival means to a majority of the poor and the extremely poor individual and, therefore, improves the quality of life of the people but has not significantly brought about inclusive growth in the region.

The interaction coefficient (ent_enex - the interaction of entrepreneurship and years of entrepreneurial experience) in Table 2 above, measuring therelevance of knowledge (R\&D) spillovers for informal entrepreneurs shows that knowledge spillovers through the experiential learning process for the development of entrepreneurial knowledge and innovation have a significant impact on inclusive growth. The knowledge that enhances the ability of individuals to recognize and act on opportunities and manage new ventures and become innovative increases entrepreneurial activities and grows entrepreneurship, and significantly enhances inclusive growth. The coefficient for the extraction of entrepreneurship and employment (ent_empl), measuring theindirect impact of informal sector employment on inclusive growth shows informal sector entrepreneurship increases informal employment and its impact is positive but not statistically significant. Informal employment is enhanced by informal entrepreneurship and, though not statistically significant, this drives inclusive growth. Income from informal employment is very low. The insignificant impact could be associated with a large subsistence informal economy with low wages and increasing poverty.

Entrepreneurial capital also positively and significantly affects inclusive growth. An increase in entrepreneurial capital leads to $19.13 \%$ increase in inclusive growth. Capital plays a key role in determining the size and success of entrepreneurship, especially in the informal sector. It promotes informal investment and enhances informal entrepreneurship growth and, through that, makes growth inclusive. The variable forfinancial or other forms of assistance showed negative 


\section{International Journal of Business Management and Economic Review}

Vol. 4, No. 05; 2021

ISSN: 2581-4664

and insignificant coefficient. This indicates that informal entrepreneurs in the region have not gotten appropriate assistance - financial or otherwise, capable of growing entrepreneurship at the informal sector.

The coefficient of determination, $\mathrm{R}^{2}$, showed a strong explanatory power of the explanatory variables, explaining $71.96 \%$ variation in inclusive growth. The F-test confirms the joint significance of the explanatory variables. The null of no joint significant impact of the explanatory variables on inclusive growth is rejected at the 5\% level. The Ramsey RESET test showed a probability value of 0.6648 . The insignificant $\mathrm{p}$-value guides us to accept the null hypothesis that the model has no omitted variables. This means that the model is properly specified.

\section{CONCLUSION AND POLICY RECOMMENDATIONS}

This study specifically examined the impact of informal sector entrepreneurship on inclusive growth and, also determine if the impact was dependent on informal employment. OLS technique was employed for the data analysis. The study has shown that informal sector entrepreneurship increases informal employment and directly impacted on inclusive growth but the indirect impact on inclusive growth through employment is insignificant. Informal wages are low but better than unemployment as it improves living standards. However, it does not make growth inclusive. Entrepreneurial experience andknowledge spillovers through the experiential learning process for the development of entrepreneurial knowledge and innovation are also good for inclusive growth. We recommended the formalization of the informal sector, however, the formalization process should not be directed towards controlling and regulating entrepreneurial activities. Instead, the formalization process should be enabling and supporting informal enterprises. The enabling methods should include the provision of suitable premises for entrepreneurs; organizing training on entrepreneurial skills development, employment practices and contracts, provision of water and electricity as well as low-interest loans and credits. This has to be sustainable for them to become gradually more mature and ultimately part of the formal sector.This process will also fast formalize the informal sector,enhance growth and will bring about an increase in employment, earnings and more suitable job conditions for the poor.

\section{REFERENCES}

Adebosin, W. (2019), Employment, poverty and inclusive growth in Nigeria (1980-2015). Available at: https://www.researchgate.net/publication/333190628 EMPLOYMENT POVERTY AND INC LUSIVE_GROWTH_IN_NIGERIA_1980-2015

Akpodono, O. S. (2016). Female Entrepreneurship and Economic Development in South-East, Nigeria. $\mathrm{PhD}$ thesis of University of Nigeria

Ali, I and Son, H. (2007), Defining and Measuring Inclusive Growth: Application to the Philippines. Asian Development Bank Economic and Research Department Working Paper No. 98. Available at: https://www.adb.org/sites/default/files/publication/28211/wp098.pdf

Anand, R., Mishra, S. and Peiris, S. J. (2013), Inclusive Growth: Measurement and Determinants. International Monetary Fund Working Paper No. 135. Available at: https://www.imf.org/external/pubs/ft/wp/2013/wp13135.pdf 


\section{International Journal of Business Management and Economic Review}

Vol. 4, No. 05; 2021

ISSN: 2581-4664

Bawa, I., A. M., Idris, A. J., Idris, and Leonard, A. O. (2017), Examining female entrepreneurship development in Nigeria: A pathway to sustainable development

Dahlquist, M. (2014), Women's informal entrepreneurship - A Force in Development: The Case of Babati, Tanzania. Published M.Sc. Thesis, Södertörn University

Eriobunah, E. C. and Nosakhare, M. E. (2013), Solutions to entrepreneurs' problems in Nigeria: A comparison with Sweden. M.Sc. Thesis. School of Management, Blekinge Institute of Technology, Sweden

Ezeibe, A. B. C., Diogu, G. O., Eze, J. U., Chiaha, G. U. and Nwokenna, E. N. (2013), Women Entrepreneurship as a Cutting Edge for Rural Development in Nigeria. Developing Country Studies, 3(5), 156-162

Georgescu, M. and Herman, E. (2019), Productive employment for inclusive and sustainable development in European Union Countries: A multivariate analysis. Sustainability, 11, 2 $-19$

Hakimian, H. (2013), The Search for Inclusive Growth in North Africa: A Comparative Approach. African Development Bank Economic Brief. Available at: https://www.afdb.org/fileadmin/uploads/afdb/Documents/Publications/Economic_Brief__The_Search_for_Inclusive_Growth_in_North_Africa-_A_Comparative_Approach.pdf

Ianchovichina, E. and Gable, S. L. (2012), What is Inclusive Growth? In Commodity Prices and Inclusive Growth in Low-Income Countries, ed. by Rabah Arezki, Catherine Pattillo, Marc Quintyn, and Min Zhu, International Monetary Fund.

Igbo, C. (2005), Modern institutional techniques and their application in Technical Vocational Education Programs of Polytechnic and Monotechnics. ETF capacity Building Workshop, Auchi, Nov 2005

IMF (2019), World Economic Outlook Data Base, April 2019

International Labour Organization (2011), A Statistical update on employment in the informal economy, Geneva. International Labour Office, Department of Statistics

Klasen, S. (2010), Measuring and monitoring inclusive growth: multiple definitions, open questions, and some constructive proposals. ADB Sustainable Development Working Paper Series, No. 12, June.

Kpelai, S. T. (2013), The impact of women entrepreneurship on economic growth in Benue State-Nigeria. Journal of Business and Management, 13(1), 7-12

Lucas, B. (2020), Impacts of Covid-19 on Inclusive Economic Growth in Middle-income Countries. K4D Helpdesk Report 811. Brighton, UK: Institute of Development Studies. Available at: https://gsdrc.org/publications/impacts-of-covid-19-on-inclusive-economicgrowth-in-middle-income-countries/

Meyer, D. F. (2017), An analysis of the short and long-run effects of economic growth on employment in South Africa. International Journal of Economics and Finance Studies, $9(1), 177-193$

Nigeria Economic Outlook (2020), Macroeconomic performance and outlook. African Economic Outlook, Supplement. Available at: https://www.afdb.org/en/countrieswest-africa-nigeria/nigeria-economic-outlook

Oduh, M., Eboh, E., Ichoku, H. \& Ujah, O. (2008), Measurement and explanation of the informalsector of the Nigerian economy. African Institute for Applied Economics (AIAE) Research Paper No. 3, August. Enugu: AIAE 


\section{International Journal of Business Management and Economic Review}

Vol. 4, No. 05; 2021

ISSN: 2581-4664

Ogbuabor, J. E. and Malaolu, V. A. (2013), Size and causes of the informal sector of the Nigerian economy: Evidence from error correction mimic model. Journal of Economics and Sustainable Development, 4(1), 85-103

Onyebueke, V. and Geyer, M. (2011), The informal sector in urban Nigeria: Reflections from almost four decades of research.SSB/TRP/MDM, (59), Available from: https://www.ajol.info/index.php/trp/article/viewFile/77222/67671. Accessed $10^{\text {th }}$ December 2017

Rauniyar, G. and Kanbur, R. (2010), Inclusive development: two papers on conceptualization, application, and the ADB perspective. January draft; Independent Evaluation Department, Manila: Asian Development Bank.

Spring, A. (2009), African women in the entrepreneurial landscape: Reconsidering the formal and informal sectors. Journal of African Business, 10, 11-30

Tarilaye, N. and Okoye, E. I. (2017), Achieving inclusive growth through entrepreneurship financing in Nigeria: Challenges and prospects. he 2017 International Conference on African Entrepreneurship and Innovation for Sustainable Development (AEISD). At: Nnamdi Azikiwe University, Awka, Nigeria

Williams, C. (2015), Informal Sector Entrepreneurship. A background paper for the OECD Centre for Entrepreneurship, SMEs and Local Development. Available at: https://www.oecd.org/employment/leed/Background-Paper-PB-Informal-

Entrepreneurship-final.pdf

World Development Report (2019). The changing nature of work. World Development Report. Available at: https://elibrary.worldbank.org/doi/full/10.1596/978-1-4648-1328-3_ch5

Yelwa, M., Obansa, S. A. J. and Owe, E. (2015), Informality, inclusiveness and economic growth in Nigeria. International Journal of Management Science and Business Administration, $1(10), 33-44$ 